\title{
MOLECULAR DOCKING STUDIES ON SOME 4,5-DIHYDRO-1H- PYRAZOLE DERIVATIVES AS CYCLOOXYGENASE INHIBITORS
}

\author{
SIKLOOKSİJENAZ INHIBBITTÖRLERI OLARAK BAZI 4,5-DIHHIDRO-1H-PIRAZOL \\ TÜREVLERI ÜZERINDE MOLEKÜLER DOKINNG ÇALIŞMALARI
}

\section{Begüm EVRANOS AKSÖZ*}

Suleyman Demirel University, Faculty of Pharmacy, Department of Pharmaceutical Chemistry, 32000, Isparta, Turkey

\begin{abstract}
Objective: To examine the interactions of some 4,5-dihydro-1H-pyrazole derivatives, which are thought to have antiinflammatory effects, with cyclooxygenase-1 (COX-1) and cyclooxygenase-2 (COX-2) enzymes, docking studies were carried out on these enzymes.

Material and Method: $C O X-1$ enzyme (3KK6) and COX-2 enzyme (3LN1) were selected from the protein data bank for docking studies. The ligand and protein constructs were prepared using Autodock 1.5.6. AutoDock Vina was used to determining the binding affinity, and Discovery Studio 3.5 was utilised to analyse and display the docking results.

Result and Discussion: As a result of the docking process on COX-1 and COX-2 enzymes, 4,5-Dihydro$1 H$-pyrazole derivatives were observed to interact with both enzymes. The 4,5-dihydro-1H-pyrazole ring was found to be important in its interactions with the COX-2 enzyme. The inclusion of a bulky group in the construct did not cause any problems in interaction with the COX-1 enzyme but eliminated some interactions with the COX-2 enzyme. To better elucidate the inhibition properties of enzymes, this study should be supported by in vitro and in vivo COX inhibition tests.
\end{abstract}

Keywords: Cyclooxygenase-1, cyclooxygenase-2, 4,5-dihydro-1H-pyrazole, inflammation, molecular docking

\section{ÖZ}

Amaç: Antiinflamatuvar etkileri olduğu düşünülen bazı 4,5-dihidro-1H-pirazol türevlerinin siklooksijenaz 1(COX-1) ve siklooksijenaz 2 (COX-2) enzimleri ile etkileşimlerini incelemek amacıla bu enzimler üzerinde docking çalışmaları yapılmıştır.

Gereç ve Yöntem: Doking çalışmaları için protein veri bankasından, COX-1 enzimi için (3KK6) ve COX2 enzimi için (3LN1) seçilmiştir. Ligand ve proteinin yapıları Autodock 1.5.6 kullanılarak hazırlanmıştır.

\footnotetext{
* Corresponding Author/Sorumlu Yazar: Begüm Evranos Aksöz e-mail / e-posta: begumevranos@gmail.com, begumaksoz@sdu.edu.tr, Phone / Tel: +902462114303
} 
Bağlanma afinitesini belirlemek için AutoDock Vina, doking sonuçlarını analiz etmek ve görüntülemek için ise Discovery Studio 3.5 kullanılmuştır.

Sonuç ve Tartışma: $C O X-1$ ve COX-2 enzimleri üzerine yapılan doking işlemi sonucunda 4,5-dihidro$1 H$-pirazol türevlerinin her iki enzimle de etkileşime girdiği görüldü. 4,5-Dihidro-1H-pirazol halkasının COX2 enzimi ile etkileşimde önemli olduğu bulundu. Yapıya hacimli bir grubun dahil edilmesi, COX-1 enzimi ile etkileşimde herhangi bir soruna neden olmazken, COX-2 enzimi ile bazı etkileşimleri ortadan kaldırdl. Enzimlerin inhibisyon özelliklerinin daha iyi aydınlatılabilmesi için bu çalışmanın in vitro ve in vivo COX inhibisyon testleri ile desteklenmesi gerekmektedir.

Anahtar Kelimeler: Siklooksijenaz 1, siklooksijenaz, 2, 4,5-dihidro-1H-pirazol, inflamasyon, moleküler doking

\section{INTRODUCTION}

Inflammation, which is the body's protective response, occurs after an injury and/or an infection aims to heal the tissue and can be chronic or acute. Acute inflammation includes a highly coordinated physiological response, beginning with constructing soluble mediators such as chemokines and cytokines. Simultaneously, circulation of leukocytes and endothelial cells are provided to the injured/infected tissue. Nonsteroidal antiinflammatory drugs target the phase of the inflammation by inhibiting cyclooxygenase (COX) enzymes [1,2].

COX enzymes classified in the myeloperoxidase family are therapeutic targets for nonsteroidal antiinflammatory drugs (NSAID) [3-5]. All clinically used NSAIDs, except aspirin modify the COX protein noncovalently. These enzymes, which play a role in the catalysis of prostaglandin biosynthesis, consist of two basic isozymes, COX-1 and COX-2 [6]. NSAIDs display their activities on both of the COX isozymes. Since the inhibition of the COX-1 enzyme is responsible for the gastrointestinal and renal adverse effects of NSAIDs, it was thought that these side effects could be eliminated only by inhibiting the COX-2 enzyme [2]. When selective inhibition of the COX-2 enzyme appeared to cause serious cardiovascular problems, a balanced inhibition of both isozymes became important $[7,8]$.

COX-1 and COX-2, which are homodimers of each other and have almost superimposable 3D structures, contain 3 and 4 high mannose oligosaccharides, respectively [6]. The active site of COX-2, unlike COX-1, includes a side pocket [9]. COX-2 enzyme has a broader substrate specificity than COX1 [6]. These enzymes, most of which are located in the lumenal region of the endoplasmic reticulum, are bifunctional [9]. Each COX monomer includes three domains: the epidermal growth factor domain, the membrane-binding domain, and the catalytic domain [6,9]. The catalytic domain, which is the site of action of nonsteroidal antiinflammatory drugs, has peroxidase and cyclooxygenase active sites $[4,6,9]$. Arachidonic acid is oxygenated in the cyclooxygenase active site, while prostaglandin G2 (PGG2) is reduced in the peroxidase active site [9].

The pyrazole ring, a 5-membered ring system containing two nitrogen atoms, and its monounsaturated derivative, the 4,5-dihydro-1H-pyrazole ring, are in the structure of many nonsteroidal antiinflammatory drugs (NSAIDs) such as antipyrine, phenazone, metamizole and phenylbutazone [2]. 
These ring systems inhibit cyclooxygenase enzymes, particularly the COX-2 enzyme [10-16]. It is thought that these compounds, whose antidepressant and antimicrobial activities we have previously published [17-19], may inhibit the COX enzymes because of their similarity to celecoxib (Figure 1), which is a selective COX-2 inhibitor in terms of chemical structure and also carrying a 4,5-dihydro- $1 \mathrm{H}$ pyrazole ring in their structure. In this study, molecular docking interactions of some 4,5-dihydro- $1 \mathrm{H}$ pyrazole derivatives with COX-1 and COX-2 enzymes were investigated.

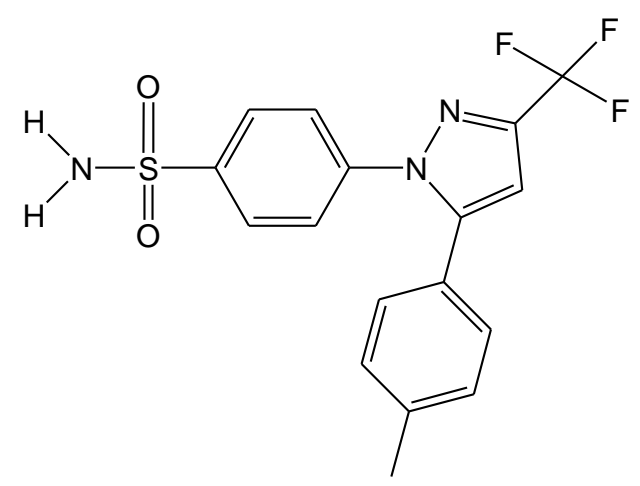

Figure 1. Formula of celecoxib

\section{MATERIAL AND METHOD}

The X-ray crystallographic structure of COX-1 (PDB: 3KK6) and COX-2 (PDB: 3LN1) were provided from Protein Data Bank [20]. 3KK6 is the crystal structure of COX-1 in complex with celecoxib, while 3LN1 is the construct of celecoxib bound at the COX-2 active site. 3KK6 has two chains. Chain A was selected. 3LN1 is composed of four symmetric chains and active sites of the protein present in all chains [21]. Chain A selected, and other chains were deleted.

For preparing the protein and ligands (Table1) and determining the Grid map, Autodock 1.5.6 [22] was used. Chain A was selected. Then, the water was deleted, and polar hydrogens and Gasteiger charges were added. A grid map was determined. ChemDraw Ultra 12.0 was utilised to draw the 2D formula of the compounds. Energy minimisation was applied with Avogadro software [23]. The docking process was realised with Autodock Vina [24], and visualisation of interactions was made by Discovery Studio 3.5 [25]. To optimise the docking process, crystal structures of celecoxib (CEL) were compared with the predicted conformations of docking results. Superimposition of crystallised form and docking results of CEL was given in Figure 2.

\section{RESULT AND DISCUSSION}

Molecular docking interactions of 4,5-dihydro-1H-pyrazole derivatives were elucidated, and it 
was observed that compounds interacted with both the COX-1 and COX-2 enzymes. When 4,5-dihydro1H-pyrazole derivatives and celecoxib were docked in the 3KK6 enzyme, various interactions with

Table 1. The formula of ligands tested in molecular docking

\begin{tabular}{|c|c|c|c|c|c|c|}
\hline & & & \multicolumn{4}{|c|}{$\mathrm{R}_{\mathrm{R}^{6}(\mathrm{Ring} 3)}$} \\
\hline Compound & $\mathbf{R}^{1}$ & $\mathbf{R}^{2}$ & $\mathbf{R}^{3}$ & $\mathbf{R}^{4}$ & $\mathbf{R}^{5}$ & $\mathbf{R}^{6}$ \\
\hline BE1 & $-\mathrm{H}$ & $-\mathrm{Br}$ & $-\mathrm{OCH}_{3}$ & $-\mathrm{H}$ & $-\mathrm{H}$ & Pyridine-4-yl \\
\hline BE2 & $-\mathrm{H}$ & $-\mathrm{Cl}$ & $-\mathrm{OCH}_{3}$ & $-\mathrm{H}$ & $-\mathrm{H}$ & Pyridine-4-yl \\
\hline BE3 & $-\mathrm{Cl}$ & $-\mathrm{Cl}$ & $-\mathrm{OCH}_{3}$ & $-\mathrm{H}$ & $-\mathrm{H}$ & Pyridine-4-yl \\
\hline BE4 & $-\mathrm{H}$ & $-\mathrm{Cl}$ & $-\mathrm{OCH}_{3}$ & $-\mathrm{H}$ & $-\mathrm{H}$ & Phenyl \\
\hline BE5 & $-\mathrm{Cl}$ & $-\mathrm{Cl}$ & $-\mathrm{H}$ & $-\mathrm{H}$ & $-\mathrm{CH}_{3}$ & Phenyl \\
\hline BE6 & $-\mathrm{H}$ & $-\mathrm{Br}$ & $-\mathrm{H}$ & $-\mathrm{H}$ & $-\mathrm{OCH}_{3}$ & Phenyl \\
\hline BE7 & $-\mathrm{H}$ & $-\mathrm{Br}$ & $-\mathrm{OCH}_{3}$ & $-\mathrm{H}$ & $-\mathrm{H}$ & Phenyl \\
\hline BE8 & $-\mathrm{H}$ & $-\mathrm{Cl}$ & $-\mathrm{H}$ & $-\mathrm{H}$ & -benzyloxy & Pyridine-4-yl \\
\hline BE9 & $-\mathrm{H}$ & $-\mathrm{Cl}$ & $-\mathrm{H}$ & $-\mathrm{OCH}_{3}$ & $-\mathrm{H}$ & Pyridine-4-yl \\
\hline BE10 & $-\mathrm{H}$ & $-\mathrm{Cl}$ & $-\mathrm{H}$ & $-\mathrm{OCH}_{3}$ & $-\mathrm{H}$ & Furan-2-yl \\
\hline
\end{tabular}



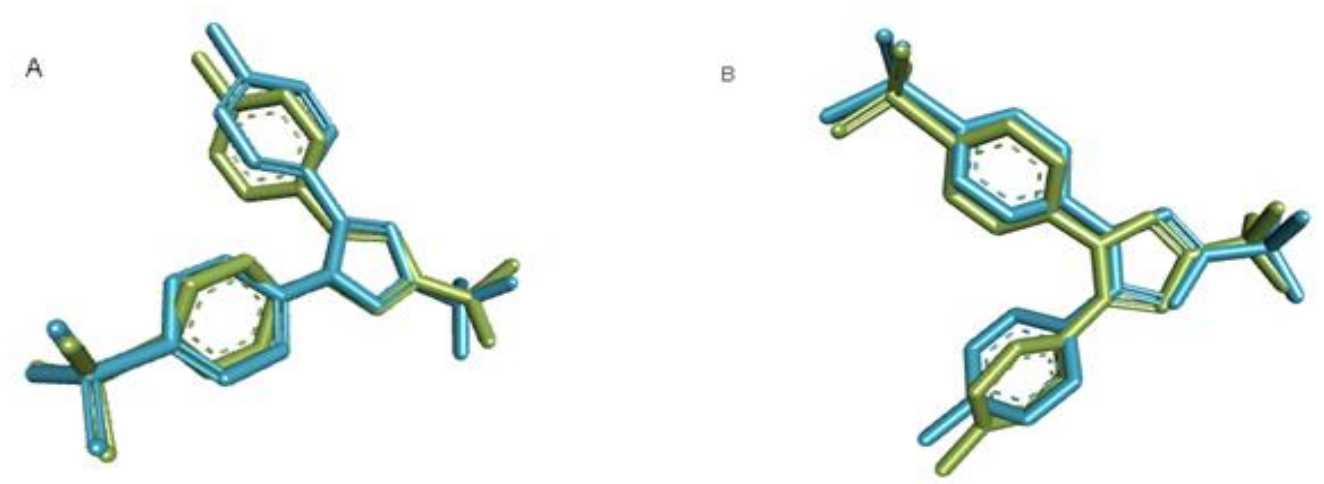

Figure 2. Superimposition of crystal form and docking result of celecoxib

A. For 3KK6, B. For 3LN1

HIS386, GLU454, PHE210, THR212, HIS207, ASP450, ASN382, LYS211, VAL291, VAL447, HIS388, ASP314, ARG307, ARG311, LYS573, GLU260, VAL261, TYR254, LYS251, TYR385, PRO218, ARG469, ILE124, ILE137, ILE46, LEU152, PRO125, GLU289, HIS274, LEU294, HIS446 amino acids were determined (Table 2). Binding energies of ligands were found between -7.3 and -9.1 $\mathrm{kcal} / \mathrm{mol}$ for the COX-1 enzyme (Table 2). Celecoxib, the native ligand, interacted with THR212, PHE210, HIS446, VAL447, HIS207 and ASN382 amino acids (Figure 3A) with a binding energy of $7.6 \mathrm{kcal} / \mathrm{mol}$. All compounds except BE6 and BE10 showed lower binding energies than celecoxib. Compound BE8 exhibited the best binding energy (-9.1 kcal/mol) with COX-1 enzyme and interacted with TYR385, VAL291, PRO218, HIS386, HIS207, GLU454, HIS388 amino acids through phenyl, pyridine, methyl and methylene groups of the molecule (Figure 3B). Compounds BE2, BE3 and BE4, displayed good interactions with the COX-1 enzyme with a binding energy of $-8.1 \mathrm{kcal} / \mathrm{mol}$. BE2 interacted with ASN382, HIS386, THR212, HIS207, VAL291, VAL447, PHE210 amino acids through phenyl, pyridine, chloro, hydroxy and methoxy groups. It made hydrogen bonds with hydroxy and methoxy groups (Figure 3C). BE3 interacted with ASN382, THR212, LYS211, VAL291, HIS207, HIS386, HIS388, PHE210 amino acids through phenyl at the 3rd position of 4,5-dihydro-1H-pyrazole ring, pyridine, chloro and hydroxy groups. BE4 interacted with HIS386, VAL291, HIS207, VAL447, PHE210, amino acids through phenyl, chloro and methoxy groups. The celecoxib was found to form two hydrogen bonds with THR212 and PHE210 inside the COX-1 enzyme. All compounds made 1 to 3 hydrogen bond interactions and some other interactions, except BE8, as shown in Table 2.

Compounds made interactions with HIS193, HIS374, PHE196, TYR371, ASN368, VAL277, VAL433, HIS372, ASN28, GLU27, LYS454, LYS64, LEU65, LYS459, PHE49, GLN440, LEU284, VAL281, LEU280, VAL430, ALA436, ARG46, ARG29, LEU60, THR47, TYR108, THR198, LYS197, LEU394, MET444, GLN189, ILE260, SER457, LEU458 amino acids in the active binding 
site of COX-2 enzyme (Table 3). Binding energies of compounds were found between -7.7 and-9.0 $\mathrm{kcal} / \mathrm{mol}$.

Table 2. Binding energy values and interaction properties of celecoxib and 4,5-dihydro-1H-pyrazole derivatives for the COX-1 enzyme

\begin{tabular}{|c|c|c|c|c|c|c|}
\hline Compound & $\begin{array}{l}\text { Binding } \\
\text { energy } \\
\text { (kcal/mol) }\end{array}$ & $\begin{array}{l}\text { Conventional } \\
\text { Hydrogen } \\
\text { Bond }\end{array}$ & $\begin{array}{l}\text { Carbon } \\
\text { Hydrogen } \\
\text { bond }\end{array}$ & $\begin{array}{l}\text { Alkyl/ } \pi \text { - } \\
\text { Alkyl }\end{array}$ & $\begin{array}{l}\pi- \\
\text { Interactions }\end{array}$ & Halogen \\
\hline BE1 & -7.7 & $\begin{array}{l}\text { HIS386, } \\
\text { GLU454, } \\
\text { PHE210 }\end{array}$ & $\begin{array}{l}\text { THR212 }^{a} \text {, } \\
\text { HIS207a }^{\text {a }} \\
\text { ASP450, } \\
\text { ASN382 }^{\text {a }}\end{array}$ & $\begin{array}{l}\text { LYS211, } \\
\text { VAL291 }\end{array}$ & $\begin{array}{l}\text { HIS207 }^{\mathrm{a}} \\
\text { HIS386 }\end{array}$ & \\
\hline BE2 & -8.1 & $\begin{array}{l}\text { ASN382, } \\
\text { HIS386 }\end{array}$ & $\begin{array}{l}\text { THR212 }^{\mathbf{a}} \text {, } \\
\text { HIS386 }\end{array}$ & $\begin{array}{l}\text { HIS207 }^{\mathrm{a}} \\
\text { VAL291, } \\
\text { VAL447 }^{\mathrm{a}}\end{array}$ & $\begin{array}{l}\text { PHE210 }^{a} \text {, } \\
\text { HIS207 }^{\text {a }} \\
\text { HIS386 }\end{array}$ & \\
\hline BE3 & -8.1 & ASN382 & THR212 $^{\mathrm{a}}$ & $\begin{array}{l}\text { LYS211, } \\
\text { VAL291, } \\
\text { HIS207a }^{2} \\
\text { HIS386, } \\
\text { HIS388, }\end{array}$ & $\begin{array}{l}\text { HIS207 }^{\mathrm{a}} \\
\text { HIS386, } \\
\text { HIS388, } \\
\text { PHE210 }^{\text {a }}\end{array}$ & \\
\hline BE4 & -8.1 & HIS386 & - & $\begin{array}{l}\text { VAL291, } \\
\text { HIS207 }^{\text {a }} \\
\text { VAL447 }^{\text {a }}\end{array}$ & $\begin{array}{l}\text { HIS207 }^{\mathrm{a}} \\
\text { HIS386, } \\
\text { PHE210 }^{\mathrm{a}}\end{array}$ & \\
\hline BE5 & -8.0 & $\begin{array}{l}\text { ASP314, } \\
\text { ARG307 }\end{array}$ & - & $\begin{array}{l}\text { ARG311, } \\
\text { LYS573, } \\
\text { ARG307 }\end{array}$ & $\begin{array}{l}\text { GLU260, } \\
\text { VAL261, } \\
\text { TYR254 }\end{array}$ & \\
\hline BE6 & -7.3 & ARG307 & - & $\begin{array}{l}\text { ARG311, } \\
\text { TYR254, } \\
\text { LYS251, } \\
\text { LYS573 }\end{array}$ & $\begin{array}{l}\text { GLU260, } \\
\text { VAL261, }\end{array}$ & \\
\hline BE7 & -8.0 & HIS386 & $\begin{array}{l}\text { THR212a, } \\
\text { ASN382 }^{\mathrm{a}}\end{array}$ & $\begin{array}{l}\text { VAL291, } \\
\text { VAL447 }\end{array}$ & $\begin{array}{l}\text { PHE210 }^{\text {a }} \\
\text { HIS207 }^{\text {a }} \\
\text { HIS386 }^{2}\end{array}$ & \\
\hline BE8 & -9.1 & & TYR385 & $\begin{array}{l}\text { VAL291, } \\
\text { PRO218 }\end{array}$ & $\begin{array}{l}\text { HIS386, } \\
\text { HIS207 }^{2}, \\
\text { GLU454, } \\
\text { HIS388 }\end{array}$ & \\
\hline BE9 & -7.8 & ARG469 & ILE124 & $\begin{array}{l}\text { ILE137, } \\
\text { ILE46, } \\
\text { LEU152, } \\
\text { PRO125 }\end{array}$ & ARG469 & \\
\hline BE10 & -7.5 & GLU289 & THR212 $^{\mathrm{a}}$ & $\begin{array}{l}\text { LYS211, } \\
\text { HIS274, } \\
\text { LEU294, } \\
\text { VAL291 }\end{array}$ & $\begin{array}{l}\text { HIS386, } \\
\text { PHE210 } \\
\text { VAL291 }\end{array}$ & \\
\hline CELECOXIB & -7.6 & $\begin{array}{l}\text { THR212 }^{\mathrm{a}} \text {, } \\
\text { PHE210 }^{\mathrm{a}}\end{array}$ & & $\begin{array}{l}\text { HIS446, } \\
\text { VAL447 }^{\mathrm{a}} \text {, } \\
\text { HIS207 }^{\mathrm{a}}, \\
\text { PHE210 }^{\mathrm{a}}\end{array}$ & HIS207 $^{\mathrm{a}}$ & ASN382 $^{a}$ \\
\hline
\end{tabular}

a. Bold amino acids show the same amino acid interactions with celecoxib 


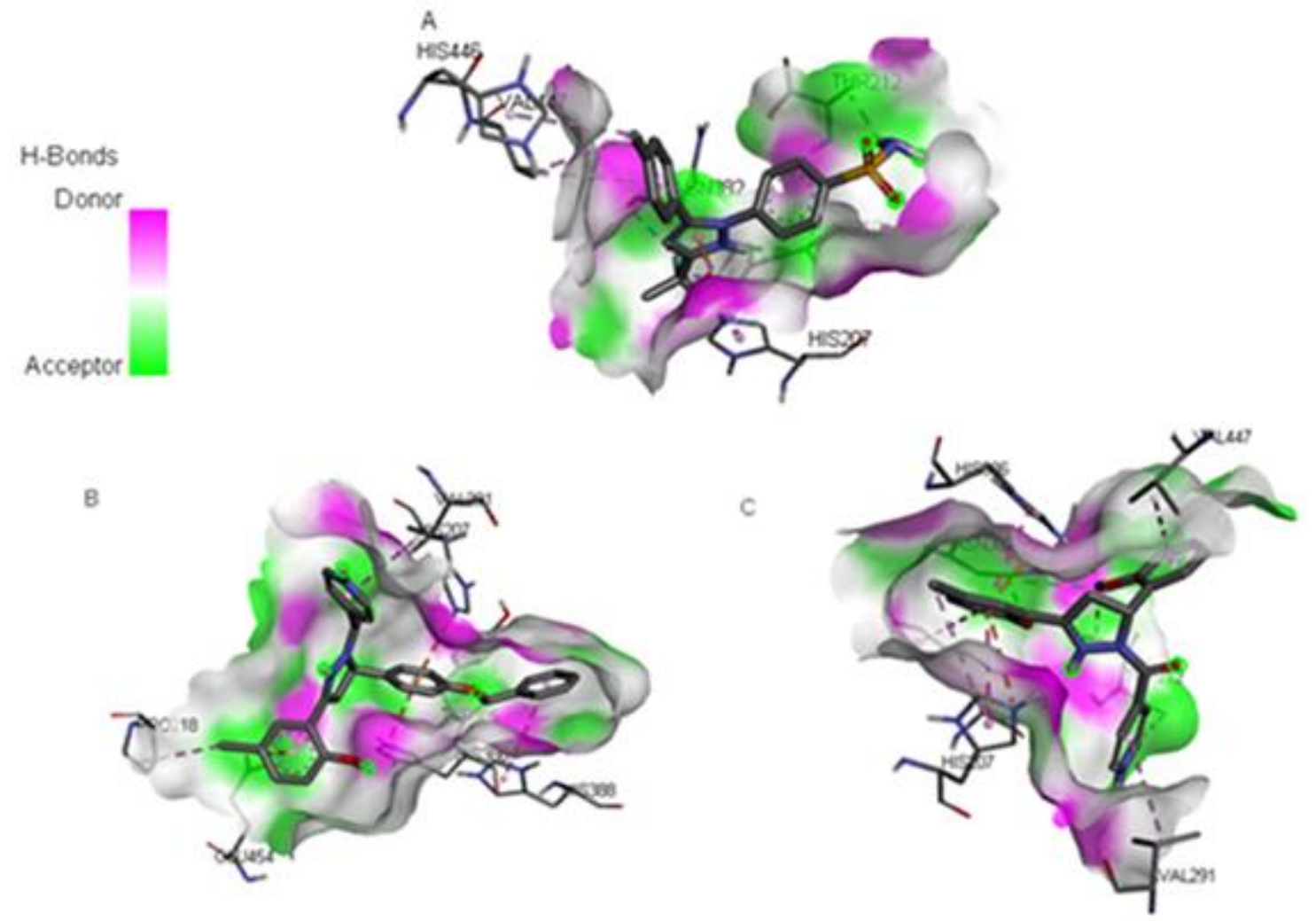

Figure 3. Molecular interactions of the COX-I enzyme

A. Docked pose of celecoxib, B. Docked pose of compound BE8, C. Docked pose of compound BE2

The celecoxib was found to form two hydrogen bonds to ARG29 and ARG46, halogen bonds, $\pi$ and alkyl interactions (Figure 4A) inside the COX-2 enzyme with a binding energy $-8.1 \mathrm{kcal} / \mathrm{mol}$ (Table 3 ). All compounds except BE1, BE7 and BE10 exhibited lower binding energies than celecoxib. BE5 and BE8 had the highest binding affinity for the COX-2 enzyme with -9 and $-8.9 \mathrm{kcal} / \mathrm{mol}$ binding energies, respectively. The carbonyl group of BE5 made a hydrogen bond to THR198. Phenyl rings at the third and fifth positions of the 4,5-dihydro-1H-pyrazole ring of this compound made $\pi$ - interactions with HIS193 and HIS372. While the phenyl ring attached to the carbonyl group made pi-alky interactions with amino acids, the methyl and chlorine groups in the compound BE5 made alkyl interactions (Figure 4B). The phenyl ring of BE8, attached to the p-position of the phenyl ring at the 5th position, made $\pi$ interactions with HIS372 and MET444. Also, BE8 made alkyl and $\pi$-alkyl interactions with chloro and the phenyl ring at position 3 of 4,5-dihydro-1H-pyrazole, respectively (Figure 4C).

A chlorine atom in ring one enhanced common interactions when the compounds were evaluated for their co-interactions with celecoxib for the COX-1 enzyme. The best mutual interactions occurred when chlorine was in the 1st ring, methoxy in the ortho position of the $2 \mathrm{nd}$ ring, and pyridine in the $3 \mathrm{rd}$ ring. The ortho position of the methoxy group in the second ring is essential for common interactions. These interactions reduced when the o-substitution in the 2 nd ring shifted to the meta or para positions. 
Table 3. Calculated binding energy values and interaction properties of celecoxib and 4,5-dihydro- $1 \mathrm{H}-$ pyrazole derivatives for the COX-2 enzyme

\begin{tabular}{|c|c|c|c|c|c|c|}
\hline Compound & $\begin{array}{l}\text { Binding } \\
\text { energy } \\
\text { (kcal/mol) }\end{array}$ & $\begin{array}{l}\text { Conventional } \\
\text { Hydrogen } \\
\text { Bond }\end{array}$ & $\begin{array}{l}\text { Carbon } \\
\text { Hydrogen } \\
\text { Bond }\end{array}$ & $\begin{array}{l}\text { Alkyl/ } \pi- \\
\text { Alkyl }\end{array}$ & $\begin{array}{l}\pi- \\
\text { Interactions }\end{array}$ & Halogen \\
\hline BE1 & -8.0 & $\begin{array}{l}\text { HIS193, } \\
\text { HIS374, } \\
\text { PHE196 }\end{array}$ & $\begin{array}{l}\text { TYR371, } \\
\text { ASN368 }\end{array}$ & $\begin{array}{l}\text { VAL277, } \\
\text { VAL433 }\end{array}$ & $\begin{array}{l}\text { HIS372, } \\
\text { HIS374, }\end{array}$ & \\
\hline$\overline{B E 2}$ & -8.3 & $\begin{array}{l}\text { ASN28 }{ }^{\mathbf{a}} \text {, } \\
\text { GLU27 }\end{array}$ & & $\begin{array}{l}\text { LYS454 }^{\mathbf{a}} \text {, } \\
\text { LYS64 }^{\text {a }} \\
\text { LEU65 }^{\mathbf{a}} \text {, } \\
\text { LYS459 }\end{array}$ & PHE49 & \\
\hline BE3 & -8.5 & $\begin{array}{l}\text { TYR371, } \\
\text { HIS374, }\end{array}$ & $\begin{array}{l}\text { GLN440, } \\
\text { HIS372 }\end{array}$ & $\begin{array}{l}\text { VAL277, } \\
\text { LEU284, } \\
\text { VAL281, } \\
\text { LEU280, } \\
\text { VAL430, } \\
\text { ALA436 }\end{array}$ & $\begin{array}{l}\text { VAL433, } \\
\text { HIS193, } \\
\text { HIS372, }\end{array}$ & \\
\hline$\overline{B E} 4$ & -8.3 & ARG46 $^{\mathrm{a}}$ & & $\begin{array}{l}\text { ARG29a }^{\text {AR }} \\
\text { LEU60 }\end{array}$ & $\begin{array}{l}\text { LYS64 }^{\mathbf{a}}, \\
\text { THR47, } \\
\text { TYR108 }^{\text {a }}\end{array}$ & \\
\hline BE5 & -9.0 & THR198 & & $\begin{array}{l}\text { VAL281, } \\
\text { LEU280, } \\
\text { LYS197, } \\
\text { VAL277, } \\
\text { HIS374, } \\
\text { VAL430, } \\
\text { PHE196, } \\
\text { HIS193, } \\
\text { HIS372, }\end{array}$ & $\begin{array}{l}\text { HIS193, } \\
\text { HIS372, }\end{array}$ & \\
\hline BE6 & -8.2 & $\begin{array}{l}\text { PHE196, } \\
\text { HIS374 }\end{array}$ & HIS193 & $\begin{array}{l}\text { LEU394, } \\
\text { VAL281, } \\
\text { VAL433, } \\
\text { VAL277 }\end{array}$ & $\begin{array}{l}\text { HIS372, } \\
\text { HIS374, } \\
\text { HIS193 }\end{array}$ & \\
\hline BE7 & -8.0 & ASN28 & & $\begin{array}{l}\text { LEU65 }^{\mathbf{a}} \\
\text { LYS454 }^{\text {a }}\end{array}$ & PHE49 & \\
\hline BE8 & -8.9 & & & $\begin{array}{l}\text { VAL277, } \\
\text { LYS197 }\end{array}$ & $\begin{array}{l}\text { HIS372, } \\
\text { MET444 }\end{array}$ & \\
\hline BE9 & -8.2 & $\begin{array}{l}\text { PHE196, } \\
\text { HIS374, } \\
\text { GLN189 }\end{array}$ & $\begin{array}{l}\text { ASN368, } \\
\text { HIS193, } \\
\text { TYR371 }\end{array}$ & $\begin{array}{l}\text { LEU280, } \\
\text { VAL281, } \\
\text { VAL277, } \\
\text { VAL433, } \\
\text { ILE260 }\end{array}$ & $\begin{array}{l}\text { HIS372, } \\
\text { HIS193, } \\
\text { HIS374 }\end{array}$ & \\
\hline BE10 & -7.7 & $\mathrm{ASN}^{2}{ }^{\mathrm{a}}$ & & $\begin{array}{l}\text { LYS64 }^{\mathbf{a}}, \\
\text { LEU65 }^{\text {a }}, \\
\text { LYS454 }^{\text {a }} \text {, } \\
\text { LYS459 }\end{array}$ & PHE49 & \\
\hline CELECOXIB & -8.1 & $\begin{array}{l}\text { ARG29, } \\
\text { ARG46 }^{\text {a }}\end{array}$ & & LYS64 $^{\text {a }}$ & $\begin{array}{l}\text { LEU65 }^{\text {a }} \\
\text { TYR108 }^{\text {a }} \text {, } \\
\text { ARG29 }\end{array}$ & $\begin{array}{l}\text { ASN28 }^{\text {a }}, \\
\text { LYS454 }^{\text {a }} \text {, } \\
\text { SER457, } \\
\text { LEU458 }\end{array}$ \\
\hline
\end{tabular}

a. Bold amino acids show similar interactions with celecoxib 


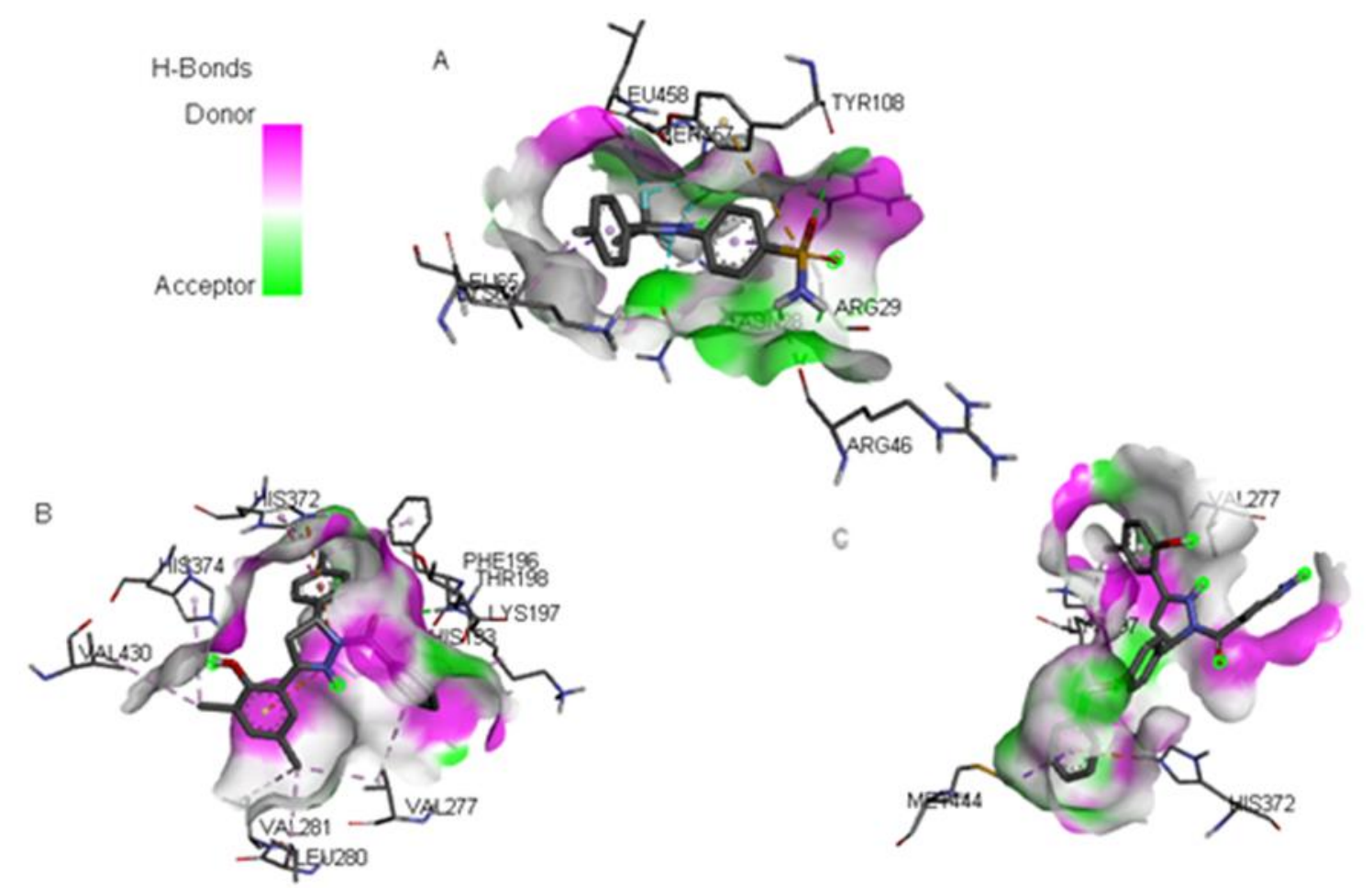

Figure 4. Molecular interactions of the COX-2 enzyme

A. Docked pose of celecoxib, B. Docked pose of compound BE5, C. Docked pose of compound BE8

Instead of o-methoxy substitution to the 2 nd ring, p-benzyloxy substitution decreased common interactions. In contrast, these interactions increased when the p-benzyloxy substitution was made to the 2nd ring instead of m-methoxy substitution. While there is chlorine in the 1st ring and o-methoxy in the 2nd ring, replacing pyridine with phenyl in the third ring decreased the mutual interactions with celecoxib. When there is the bromine in the 1st ring and o-methoxy substitution in the 2nd ring, replacing the pyridine with phenyl in terms of co-interactions with celecoxib didn't make much difference. When the methoxy attached to the 2nd ring was in the meta position, and there was chlorine in the 1st ring, replacing the pyridine in the third ring with furyl increased the mutual interactions. Co-interactions with celecoxib disappeared when the 2nd ring had a methyl or methoxy group at the para position, and the 3rd ring was phenyl. A bromine atom in the 1st ring or two chlorine atoms in the 3rd and 5th positions did not make a big difference in mutual interactions.

When the interaction similarities of the compounds with celecoxib were evaluated in terms of the COX-2 enzyme, it was observed that replacing the chlorine atom in the 1st ring with bromine decreased the common interactions. In the presence of chlorine atoms in the $3 \mathrm{rd}$ and 5 th positions of the 1 st ring, these interactions were disappeared. While there was chlorine in the 1st ring and m-methoxy in the 2nd ring, the common interactions vanished due to the displacement of the furan with pyridine as the 3rd ring. In the presence of bromine in the 1 st ring and o-methoxy in the 2 nd ring, these interactions disappeared when the phenyl in the 3rd ring was replaced by pyridine. While the 1st ring was substituted 
with chlorine, the 2nd ring with an o-methoxy group, the 3rd ring is phenyl or pyridine did not make a big difference in mutual interactions. When the p-benzyloxy group replaced the methoxy group in the ortho position of the second ring, the common interactions disappeared. While there was chlorine in the 1 st ring and pyridine in the 3rd ring, these interactions were lost when the methoxy group in the 2nd ring moved from the ortho position to the meta position.

Consequently, the compounds interacted with both of the COX-enzymes. The phenyl ring in the 3rd position of the 4,5-dihydro-1H-pyrazole is essential in interaction with the COX-1 and COX-2 enzymes, and this phenyl interacted with amino acids in all compounds. Compounds made hydrogen bonds to their methoxy, hydroxy or carbonyl groups for the COX-1 enzyme. With the introduction of a bulky group such as benzyloxy into the structure of the BE8 compound, the interaction between the pyridine ring and amino acids for the COX-2 enzyme has disappeared. The introduction of the bulky group into the structure did not abolish the interaction between the pyridine ring and amino acids for the COX-1 enzyme. The compounds' methoxy, hydroxy, carbonyl, and 4,5-dihydro-1H-pyrazole groups made hydrogen bonds with the COX-2 enzyme. While the 4,5-dihydro-1H-pyrazole ring did not interact with the COX-1 enzyme, it played a role in interactions with the COX-2 enzyme. The 4,5-dihydro- $1 \mathrm{H}-$ pyrazole ring is essential in interactions with the COX-2 enzyme, and this ring made hydrogen bonds with ASN28 in these interactions. In vivo and in vitro COX inhibition tests of these substances are required to obtain more detailed information about their inhibition properties.

\section{AUTHOR CONTRIBUTIONS}

Concept: B.E.A.; Design: B.E.A.; Control: B.E.A.; Sources: B.E.A.; Materials: B.E.A.; Data Collection and / or Processing: B.E.A.; Analysis and / or Interpretation: B.E.A.; Literature Review: B.E.A.; Manuscript Writing: B.E.A.; Critical Review: B.E.A.; Other: B.E.A.

\section{CONFLICT OF INTEREST}

The author declares no conflict of interest.

\section{REFERENCES}

1. Fullerton, J., Gilroy, D. (2016). Resolution of inflammation: a new therapeutic frontier. Nature Reviews Drug Discovery, 15, 551-567. [CrossRef]

2. Mantzanidou, M., Pontiki, E., Hadjipavlou-Litina, D. Pyrazoles and pyrazolines as antiinflammatory agents (2021). Molecules, 26(11), 3439. [CrossRef] 
3. Turini, M.E., DuBois, R.N. (2002). Cyclooxygenase-2: A therapeutic target. Annual Review of Medicine, 53, 35-57. [CrossRef]

4. Chandrasekharan, N., Simmons, D.L. (2004). The cyclooxygenases. Genome Biology, 5(9), 241. [CrossRef]

5. Zarghi, A., Arfaei, S. (2011). Selective COX-2 inhibitors: A review of their structure-activity relationships. Iranian Journal of Pharmaceutical Research, 10(4), 655-683. [CrossRef]

6. Rouzer, C.A., Marnett L.J. (2009). Cyclooxygenases: structural and functional insights. Journal of Lipid Research, 50, S29-34. [CrossRef]

7. Carvalho, L.C.R., Ribeiro, D., Seixas, R.S.G.R., Silva, A.M.S., Nave, M., Martins, A.C., Erhardt, S., Fernandes, E., Cabrita, E.J., Marques, M.M.B. (2015). Synthesis and evaluation of new benzimidazole-based COX inhibitors: a naproxen-like interaction detected by STD-NMR. RSC Advances, 5, 49098-49109. [CrossRef]

8. Ju, Z., Su, M., Hong, J., La Kim, E., Moon, H.R., Chung, H.Y., Kim, S., Jung, J.H. (2019). Design of balanced COX inhibitors based on antiinflammatory and/or COX-2 inhibitory ascidian metabolites. European Journal of Medicinal Chemistry, 180, 86-98. [CrossRef]

9. Blobaum, A.L., Marnett, L.J. (2007). Structural and functional basis of cyclooxygenase inhibition. Journal of Medicinal Chemistry, 50(7), 1425-1441. [CrossRef]

10. El-Sayed, M.A., Abdel-Aziz, N.I., Abdel-Aziz, A.A., El-Azab, A.S., ElTahir, K.E. (2012). Synthesis, biological evaluation and molecular modeling study of pyrazole and pyrazoline derivatives as selective COX-2 inhibitors and antiinflammatory agents. Part 2. Bioorganic and Medicinal Chemistry, 20(10), 3306-3316. [CrossRef]

11. El-Feky, S.A.H., El-Sami, Z.K.A., Osman, N.A., Lashine, J., Kamel, M.A., Thabet, H.K. (2015). Synthesis, molecular docking and antiinflammatory screening of novel quinoline incorporated pyrazole derivatives using the Pfitzinger reaction. Bioorganic Chemistry, 58, 104-116. [CrossRef]

12. Abdelall, E.K.A., Lamie, P.F., Ali, W.A.M. (2016). Cyclooxygenase-2 and 15-lipoxygenase inhibition, synthesis, antiinflammatory activity and ulcer liability of new celecoxib analogues: Determination of region-specific pyrazole ring formation by NOESY. Bioorganic and Medicinal Chemistry Letters, 26(12), 2893-2899. [CrossRef]

13. Abdellatif, K.R., Elsaady, M.T., Abdel-Aziz, S.A., Abusabaa, A.H. (2016). Synthesis, cyclooxygenase inhibition and antiinflammatory evaluation of new 1,3,5-triaryl-4,5-dihydro- $1 \mathrm{H}$ pyrazole derivatives possessing methanesulphonyl pharmacophore. Journal of Enzyme Inhibition and Medicinal Chemistry, 31(6), 1545-1555. [CrossRef]

14. Gedawy, E.M., Kassab, A.E., El Kerdawy, A.M. (2020). Design, synthesis and biological evaluation of novel pyrazole sulfonamide derivatives as dual COX2/5-LOX inhibitors. European Journal of Medicinal Chemistry, 189, 112066. [CrossRef]

15. Akhtar, W., Marella, A., Alam, M.M., Khan, M.F., Akhtar, M., Anwer, T., Khan, F., Naematullah M., Azam, F., Rizvi, M.A., Shaquiquzzaman, M.(2021). Design and synthesis of pyrazolepyrazoline hybrids as cancer-associated selective COX-2 inhibitors. Archive der Pharmazie, 354, e2000116. [CrossRef] 
16. Costa, R.F., Turones, L.C., Cavalcante, K.V.N., Rosa Júnior, I.A., Xavier, C.H., Rosseto, L.P., Napolitano, H.B., Castro, P.F.D.S., Neto, M.L.F., Galvão, G.M., Menegatti, R., Pedrino, G.R., Costa, E.A., Martins, J.L.R., Fajemiroye, J.O. (2021). Heterocyclic compounds: pharmacology of pyrazole analogs from rational structural considerations. Frontiers in Pharmacology, 12, 666725. [CrossRef]

17. Evranos Aksoz, B., Ucar, G., Yelekçi, K. (2017). Design, synthesis and hMAO inhibitory screening of novel 2-pyrazoline analogues hMAO inhibitory screening of novel 2-pyrazolines. Combinatorial Chemistry and High Throughput Screening, 20, 510-521. [CrossRef]

18. Evranos Aksoz, B., Ucar, G., Taş S.T., Aksoz, E., Yelekci, K., Erikci, A., Sara, Y., Iskit, A.B. (2017). New hMAO-A inhibitors with potential antidepressant activity: design, synthesis, biological screening and evaluation of pharmacological activity. Combinatorial Chemistry and High Throughput Screening, 20, 461-473. [CrossRef]

19. Evranos Aksöz, B., Gürpınar, S.S., Eryılmaz, M. (2020). Antimicrobial activities of some pyrazoline and hydrazone derivatives. Turkish Journal of Pharmaceutical Science, 17, 500-505. [CrossRef]

20. Protein Data Bank (PDB) https://www.rcsb.org/ [CrossRef]

21. Flamandita, D., Sahlan, M., Lischer, K., Pratami, D.K. (2019). Molecular docking study of antiinflammatory biomarkers in sulawesi propolis as potent inhibitors of cyclooxygenase-2. in $2 n d$ IEEE International Conference on Innovative Research and Development, ICIRD 2019, 9074773, Institute of Electrical and Electronics Engineers Inc., Depok, Indonesia, 28/06/19. [CrossRef]

22. AutoDockTools, the free GUI for AutoDock. [http://autodock.scripps.edu/resources/adt]. [CrossRef]

23. Hanwell, M.D., Curtis, D.E., Lonie, D.C., Vandermeersch, T., Zurek, E., Hutchison, G.R. (2012). "Avogadro: An advanced semantic chemical editor, visualisation, and analysis platform". Journal of Cheminformatics, 4, 17. [CrossRef]

24. Trott, O., Olson, A.J. (2010). AutoDock Vina: improving the speed and accuracy of docking with a new scoring function, efficient optimisation and multithreading. Journal of Computational Chemistry, 31, 455-461. [CrossRef]

25. Barnum, D., Greene, J., Smellie, A. and Sprague, P. (1996). Identification of common functional configurations among molecules. Journal of Chemical Information and Computer Sciences 36, 563-571. [CrossRef] 